This item was submitted to Loughborough's Research Repository by the author.

Items in Figshare are protected by copyright, with all rights reserved, unless otherwise indicated.

\title{
Bridging knowledge gaps: returnees and reverse knowledge spillovers from Chinese local firms to foreign firms
}

PLEASE CITE THE PUBLISHED VERSION

http://dx.doi.org/10.1007/s11575-013-0185-0

\section{PUBLISHER}

(c) Springer-Verlag

\section{VERSION}

AM (Accepted Manuscript)

\section{PUBLISHER STATEMENT}

This work is made available according to the conditions of the Creative Commons Attribution-NonCommercialNoDerivatives 4.0 International (CC BY-NC-ND 4.0) licence. Full details of this licence are available at: https://creativecommons.org/licenses/by-nc-nd/4.0/

\section{LICENCE}

CC BY-NC-ND 4.0

\section{REPOSITORY RECORD}

Liu, Xiaohui, Jiangyong Lu, and Seong-jin Choi. 2013. "Bridging Knowledge Gaps: Returnees and Reverse Knowledge Spillovers from Chinese Local Firms to Foreign Firms". Loughborough University. https://hdl.handle.net/2134/16707. 
Bridging knowledge gaps: returnees and reverse knowledge spillovers from

Chinese local firms to foreign firms

\author{
Prof. Xiaohui Liu* \\ School of Business and Economics \\ Loughborough University \\ Leicestershire LE11 3TU \\ Tel: + 44 (0)1509 223349 \\ Fax: +44 (0) 1509223960 \\ E-mail: X.Liu2@lboro.ac.uk
}

Dr. Jiangyong Lu

Department of Strategic Management

Guanghua School of Management

Peking University

Beijing, China, 100871

Tel: +86(0)10 62757913

Email: lujiangyong@gsm.pku.edu.cn

\author{
Dr. Seong-jin Choi \\ School of Business \\ Hanyang University \\ Seoul, Korea, 133-791 \\ Tel: 82-2-2220-2686 \\ Email: seongjin@hanyang.ac.kr
}

Forthcoming in Management International Review

${ }^{*}$ Corresponding author. 


\title{
Bridging knowledge gaps: returnees and reverse knowledge spillovers from
}

\section{Chinese local firms to foreign firms}

\begin{abstract}
Adopting a knowledge-based perspective and embeddedness theory, this study examines the impact of reverse knowledge spillovers from local Chinese firms to foreign firms using a sample of high-tech firms in Zhongguancun Science Park in China. It also investigates whether returnees in foreign firms help bridge knowledge gaps between local firms and foreign firms. The results show that the presence of returnee CEOs and returnee employees enhances the impact of reverse technological and marketing spillovers on the innovation and financial performance of foreign firms. The findings call for more studies on the social dimensions of knowledge spillovers across international boundaries and have important theoretical and practical implications.
\end{abstract}

Keywords: Emerging economies; returnees; embeddedness; foreign firms, reverse knowledge spillovers 


\section{Introduction}

The existing literature on knowledge spillovers has traditionally focused on how local firms in developing countries benefit from the entry of foreign firms (Blalock and Simon 2009; Blomstrom and Kokko 1998; Buckley et al. 2002; Gong and Girma 2008; Keller and Yeaple 2003; Tian 2007). However, whether and under what conditions foreign firms receive reverse knowledge spillovers from local firms in developing countries is largely underexplored. Such an omission limits our understanding of knowledge flows in the context of the rapid rise of emerging economies such as China. Chinese firms which have lagged behind firms from developed countries in the past are now rapidly catching up with their Western counterparts. Such a new development raises the possibility that Western MNEs may learn from local Chinese firms, and reverse knowledge spillovers may take place. Hence, the rapid development of Chinese firms challenges the dominant belief that developed countries are the only source of advanced technology and that knowledge flows are unidirectional and asymmetrical, from Western MNEs to local firms in emerging economies.

Within this context, China has attracted a large number of returnees who are native Chinese and who have returned to China after several years of education and business experience abroad. These returnees may play a significant role in transferring best practice and cutting edge technology but may also be a new channel for knowledge flows between MNEs and local Chinese firms. In particular, many returnees have been employed in managerial positions within MNEs that were traditionally occupied by expatriates. These returnees often understand multiple cultures, possess cross-cultural communication skills and a global perspective, and may act as a 'bridge' between the MNEs they work for and local firms in their home country. However, very few studies have examined how returnees affect knowledge flows between local and foreign firms. There is a lack of research systematically assessing the impact of Chinese firms' rapid technological catch-up on foreign firms, and the role of returnees in reverse knowledge spillovers.

Existing studies on reverse knowledge spillovers have mainly focused on knowledge flows between the headquarters of MNEs and their subsidiaries without delineating how MNE subsidiaries acquire external knowledge in developing host countries in the first place (Eden 2009; Frost, et al. 2002; Gupta and Govindarajan 2000). Although Wei et al. (2008) examined mutual knowledge spillovers between foreign firms and Chinese firms, they only focused on local knowledge obtained by foreign firms without considering the increasing importance of Chinese firms in innovation. To extend our understanding of knowledge exchanged in both directions between local and foreign firms, and the impact of returnees on such knowledge flows in emerging economies, we examine the performance implications of reverse knowledge spillovers. Specifically, we investigate two research questions: (1) Are foreign firms able to gain reverse knowledge spillovers from local firms to enhance firm performance when they operate in emerging economies, 
and (2) Do returnees who work for foreign firms help to bridge knowledge gaps and enhance the impact of such reverse knowledge spillovers on the performance of foreign firms?

We incorporate the knowledge-based perspective and embeddedness theory into the existing literature on economic externalities (Arrow 1962; Lucas 1988; Romer 1994) to study the role of returnees in absorbing external knowledge. This integrated framework helps capture the characteristics of tacit knowledge as well as barriers to knowledge flows, and emphasizes that knowledge diffusion is socially embedded, and absorbing external knowledge is contingent on social relations. In particular, our integrated approach explains how returnees with the advantage of cultural embeddedness facilitate knowledge spillovers from local firms to foreign firms in an emerging economy.

This paper makes a number of contributions. First, we challenge the dominant view of one-way knowledge spillovers from foreign firms to local firms in emerging economies, and our findings provide new insights into recent knowledge flows between developed and emerging economies, and enrich the debate on reverse knowledge spillovers from local firms in an emerging economy to foreign firms. While existing studies on reverse knowledge transfer have mainly focused on the movement of knowledge from subsidiaries to the headquarters of MNEs, or among subsidiaries with rare exceptions (Wei, et al., 2008), we extend this line of research by investigating how foreign firms gain external knowledge when operating in a developing host country. Such a focus enables us to capture the impact of the rising technological capability of firms from emerging economies.

Second, we move beyond existing studies by considering a recent phenomenon, returnees in emerging economies, and shed new light on the special role of returnees in knowledge flows between foreign and local firms. We emphasize the knowledge-based and embeddedness perspectives in reverse knowledge spillovers. This integrated approach enriches our understanding of the social aspects of knowledge flows and helps to provide new insights into the role of individuals with special characteristics in inter-firm knowledge spillovers. Extending existing studies on the relationship between socialization and knowledge flows (Ahuja et al. 2008; Eapen 2012; Najafi-Tavani, et al., 2012; Spencer, 2008), we go a step further to investigate whether returnees help to bridge knowledge gaps between local firms and foreign firms and increase the effectiveness of reverse knowledge spillovers. The findings help advance research on knowledge flows by placing more emphasis on returnees as a special channel of reverse knowledge spillovers.

Finally, our study provides new empirical evidence on the condition under which reverse knowledge spillovers occur as few studies have empirically tested how socio-cultural dimensions of returnees affect reverse knowledge flows from local firms to foreign firms in an emerging economy. The findings from our study have important policy and managerial implications. By strategically utilising returnees, foreign firms are able to gain both local technological and marketing knowledge in emerging economies, and such knowledge flows have important performance implications for foreign firms. 


\section{Theory and Hypotheses}

In this study, we incorporate the knowledge-based perspective and embeddedness theory into the existing literature on knowledge spillovers based on economic externalities (Arrow 1962; Lucas 1988; Romer 1994). External knowledge spillovers occur when a firm 'cannot capture all quasi-rents due to its productive activities, or to the removal of distortions by the subsidiary's competitive pressure' (Caves 1974, p. 176). They arise from both intended and unintended communications between economic agents over time (David and Rosenbloom 1990). It is assumed in the economic literature on externalities that once knowledge is created, it becomes a public good and automatically spills to other parties involved (Coe and Helpman 1995; Lucas 1988; Romer 1994). However, such an assumption does not take account of the tacit nature of knowledge (Grant 1996; Nonaka and Takeuchi 1995) and does not reflect the fact that knowledge is 'sticky' i.e. often difficult to transfer within a firm, let alone as inter-firm knowledge spillovers across international boundaries (Szulanski et al. 2004). In contrast, the knowledge-based perspective focuses on the importance of knowledge creation and acquisition in sustaining competitive advantage, and highlights the fact that knowledge tends to be socially complex, embedded, and tacit (Grant 1996; Nonaka 1994). This implies that external knowledge spillovers are a complex social process, and this has largely been ignored in the existing literature on knowledge spillovers (Eapen 2012).

Moreover, although the difficulties and challenges in absorbing external knowledge have been recognized, existing research has primarily focused on how organisational features, such as internal knowledge stock and technical capabilities, or the absorptive capacity of recipient firms, affect the extent of knowledge spillovers (Blalock and Simon 2009; Cohen and Levinthal 1990; Lane et al. 2006). Hence, the concept of absorptive capacity is 'under-socialised' and does not take account of how the characteristics of individuals within an organization affect inter-firm knowledge flows across borders. To complement prior research in this area, we incorporate embeddedness theory into the spillover literature and consider a new knowledge facilitator, returnees, who may help bridge knowledge gaps between foreign and local firms. Our approach helps to reflect the 'sticky' nature of knowledge, and barriers to knowledge flows, and pays particular attention to how socio-cultural embeddedness affects cross-border knowledge spillovers. In particular, we examine how returnees in foreign firms affect reverse knowledge spillovers from local firms to foreign firms.

Embeddedness theory was originally developed in law and sociology (Granovetter 1985; Macneil 1980, 1999), and has been adopted in strategy and international business research (Jones et al. 1997; Nohria and Eccles, 1992). It is used to explain how social structure provides access benefits in inter-firm networks. More specifically, 'embeddedness refers to the social, cultural, political, and cognitive structuration of decisions in economic contexts' (Beckert 2003, p. 769). This theory highlights the social dimensions of economic actions and assumes that economic behavior 'is closely 
embedded in networks of interpersonal relations' (Granovetter 1985, p. 504). This relational focused perspective is highly relevant to understanding the special role played by returnees in knowledge spillovers as returnees are characterized by their intercultural competences and their ability to bridge transnational and local contexts, and resolve the tension between internal organizational requirements within an MNE and local conditions in a host country (Obukhova, 2011; Saxenian, 2006; Tung, 2008 ). Their socio-cultural embeddedness may help them to build close linkages between foreign firms and local firms when they operate in multi-contextual environments. We argue that the special characteristics of returnees are crucial for obtaining local technological and marketing knowledge and are able to compensate for the liability of the foreignness of MNEs in a host country. Based on our integrated framework, we develop a number of testable hypotheses.

\section{Reverse technological spillovers from local firms to foreign firms}

Existing studies on knowledge spillovers have predominantly focused on the spillover effect from foreign firms to local firms in developing countries since foreign firms possess advanced technology, well-known brands and managerial capabilities (Buckley et al. 2002; Gong and Girma, 2008; Liu and Buck 2007). A number of channels for knowledge spillover have been identified, including competition effect, demonstration effect and inter-firm labour mobility (Gong and Girma 2008; Tian 2007). Knowledge spillovers from foreign firms to local firms in developing host countries have been regarded as an effective way of technology catch up by local firms (Marin and Bell, 2006; Wei and Liu, 2006). However, the extent literature has taken a static view of one-way knowledge flows without considering the recent development and rapid catch-up of local firms in emerging economies, such as China. The development of local Chinese firms may represent potential opportunities for foreign firms to gain reverse knowledge spillovers for two main reasons. First, over the last decade the Chinese government has invested heavily in R\&D, and its share of the world's total R\&D expenditure rose to $12.3 \%$ in 2010 from $5.0 \%$ in 2002 , placing it second only to the U.S. (UNESCO, 2012).

China has climbed the innovation ladder rapidly and there has been an impressive increase in innovation activities in China. The transformation of China from a global manufacturing center to one of the innovation centers of the world may facilitate the process of reverse innovation from China to developed countries (Bruche 2009; Govindarajan and Ramamurti 2011). Some studies have shown that Chinese innovation is probably as technologically advanced as that in the West, and western multinationals increasingly use inventors located in China to enhance innovation (Griffith and Miller 2011). Just as previous studies have found that local firms are able to obtain new technology from foreign firms, those foreign firms operating in China may benefit from the growth of local firms. We posit that the recent development and transformation of Chinese firms from low cost producers to innovators may create opportunities for foreign firms to adopt locally invented technology. This implies that improvements in the R\&D infrastructure and the technology 
advancement of Chinese firms may represent potential knowledge spillovers, and may affect the innovation performance of foreign firms through technological spillovers.

Second, MNEs are considered a complex knowledge system and have the tendency to seek local technology when operating in a host country (Cantwell and Mudambi 2011; Sarkar 2011). Local firms have long been recognized as being able to quickly develop tailored products for local customers, whereas MNEs often do not have this flexibility (Wei et al. 2008). Locally invented technology produced by indigenous firms is often more suitable to local conditions, thus stimulating MNEs' to address local needs more directly, and to respond to local market constraints. In this regard, MNEs may adopt an exploratory approach to acquiring local technology. In other words, foreign firms may have the need to learn from locally invented technology and draw upon unique local innovative capabilities (Prahalad 2005). Knowledge originating in diverse locations is considered an important source of innovation (Buckley and Carter 1996). In particular, foreign firms in developed countries need to learn how to serve consumers at the bottom of the pyramid and how to compete against their local rivals in the host country (Govindarajan and Ramamurti 2011). This implies that technological flows are not merely unidirectional from foreign firms to local firms in developing host countries as identified in the existing literature. Hence, we propose

Hypothesis 1: The innovation performance of foreign firms is positively associated with reverse technological spillovers from local firms.

\section{Reverse marketing knowledge spillovers from local firms to foreign firms}

It is recognised that advanced technology, although very important, is not sufficient for the success of foreign firms in a host country as advanced technological knowledge does not guarantee foreign firms' business success (Casson 2003). To be successful in the host country, a foreign firm needs to possess not only advanced technology but also marketing knowledge and skills for commercialising new ideas and new technologies. The exploitation of advanced technology requires access to marketing techniques as well as distribution channels. Such exploitation may also require foreign firms to develop products that fit local customer needs (Fredric et al. 2006). Therefore, marketing knowledge is crucial for firm performance. However, marketing knowledge is location-specific (Anand 2002), and marketing knowledge developed by an MNEs' parent may not be directly applicable to the host country due to social and cultural differences between the home country of foreign firms and the host country (Fang et al. 2010).

In addition, firms operating abroad may suffer from the liability of foreignness and often lack local knowledge, including the understanding of local markets as well as cultural and environmental conditions and, hence, they may not effectively manage their marketing efforts (Inkpen and Beamish 1997). Such knowledge is based on a deep understanding of consumer preferences, social norms, and the cultural environment (Fang et al. 2010). Specifically, 
foreign firms need to learn how consumers respond to different advertising media and to various promotional tactics. Such knowledge can only be obtained locally by observing how local firms advertise their products and conduct their marketing campaigns. In other words, foreign firms may need to acquire marketing knowledge by watching and imitating the marketing tactics adopted by local firms. Gaining local marketing knowledge can complement a firm's ownership advantages and help the firm overcome the liability of foreignness, thus improving the firm's financial performance (Makino and Delios 1996). These arguments suggest:

Hypothesis 2: The financial performance of foreign firms is positively associated with reverse marketing knowledge spillovers from local firms.

\section{Returnees and the effectiveness of reverse knowledge spillovers}

As we discussed above, obtaining external knowledge across international boundaries is not straightforward, and prior studies of knowledge exchange at individual level (Allen 1990; Ensign and Hébert 2009; 2010) have found that social relationships of individuals affect knowledge diffusion. This literature has suggested that knowledge receivers and knowledge senders need to share a common ground and understand the social and cultural context in which knowledge is developed (Buckley et al., 2005; Harzing, et al., 2011). Following this line of research, we propose that the sociocultural embeddedness of individuals should be taken into account when examining cross-border knowledge spillovers. Drawing on the literature on embeddedness (Jones et al. 1997; Nohria and Eccles 1992; Uzzi and Gillespie 2002), we consider whether the special characteristics of returnees help to overcome cognitive barriers to knowledge spillovers, and enhance the effectiveness of such knowledge flows. In particular, we argue that returnees are embedded in multicultural contexts, and their cultural background and language skills help them to engage with local counterparts more directly and effectively than expatriate managers in their home country. In this regard, returnees may act as boundary spanners by bridging foreign and local firms (Choudhury 2010).

Existing research shows that knowledge acquisition is considered a process of socialisation which involves communication and trust so that knowledge generators and knowledge receivers need to share common ground and develop mutual trust in order for knowledge to be transmitted (Nonaka and Takeuchi 1995; Zou and Ghauri, 2008). Foreign firms' opportunities to communicate with local firms depend to a large degree on the socio-cultural embeddedness of their managers and employees (Bouty 2000). Accordingly, the frequency and effectiveness of interfirm knowledge spillovers are contingent on social and cultural connections (Liu et al. 2010). We posit that returnees may have more opportunities to interact with their counterparts in local firms, which will help to enhance reverse knowledge flows so that firms with returnees may extract more local knowledge due to their socio-cultural embeddedness. 
Firstly, returnees' cultural embeddedness helps to create a sense of identity with their counterparts in local firms in their home country. Such a sense of identity increases the willingness of local counterparts to exchange information and knowledge, which expatriates of foreign firms would have difficulty in doing (Bresman et al. 2010; Reagans and McEvily 2003). Hence, sharing the same identity may help overcome barriers to reverse knowledge flows from local firms to foreign firms.

Secondly, returnees have cultural advantages when they operate in their home country. Such advantages may facilitate them building and maintaining trust with local counterparts. This differentiates returnees from expatriates who may have greater difficulties gaining trust and developing a close relationship with local counterparts (Child and Rodrigues 1996). In particular, sharing the same language and culture with local customers, returnees are better able than expatriates to understand preferences specific to the local market. This allows returnees to be better positioned to draw on local technological and marketing knowledge to enhance firm performance (Makino and Inkpen 2003).

Thirdly, returnees are likely to establish local networks and tap into network resources and information. This represents a unique advantage for returnees since they may often quickly establish informal networks and may be more easily accepted in the local business circle. In contrast, expatriates often find it difficult to be part of the local business circle or informal networks in a host country (Bonache and Brewster 2001). In this sense, returnees have an advantage over expatriates as they understand both the overall strategies of MNEs and local conditions. Networks established by returnees may help them to access valuable and tacit local knowledge. Returnees' personal networks and closeness to local communities in their home country also enable them to overcome the liability of foreignness, thus enhancing reverse knowledge spillovers and boosting firm performance. Therefore, we propose

Hypothesis 3a: The presence of returnees enhances the effect of reverse technological knowledge spillovers on the innovation performance of foreign firms.

Hypothesis 3b: The presence of returnees enhances the impact of reverse marketing knowledge spillovers on the financial performance of foreign firms.

\section{Data and Methodology}

We tested our hypotheses with a dataset of high-tech firms in Beijing's Zhongguancun Science Park (ZSP). Established in 1988 and located in the heart of China's Capital, ZSP is one of the most dynamic high-tech clusters in China with the aspiration of becoming one of the leading technology and innovation centers in the world (Tan, 2006). As of 2010, 1.16 million employees worked in the 233 square kilometers region and generated a total value-added of 40 billion USD (i.e., 34,000 USD value-added per employee). In comparison, there were 1.31 million employees working in the 4,800 
square kilometers region of Silicon Valley in 2010, who generated a total of 170 billion USD value-added (i.e., about 130,000 USD value added per employee). ZSP has attracted a large amount of foreign investment and domestic investment and is also one of the most attractive locations for Chinese returnees. By the end of 2010, around 15,000 returnees worked for high-tech firms in ZSP and more than 70 percent had obtained master degrees or above during their study overseas. ${ }^{1}$ Concentrating in a relatively small area, ZSP has formed an ecosystem in which interactions among firms are intensive, and hence foreign firms may benefit from reverse technological and marketing spillovers from local sources, especially with help from returnees.

Starting from the middle of 1990s until the middle of 2000s, all high-tech firms in ZSP were required to report their annual financial statements to the Administrative Committee of ZSP. Similar to previous studies using the same dataset ( $\mathrm{Li}$ et al. 2012; Todo et al. 2011), we focus on the sample period of 1996-2003. The dataset provides information on a wide range of firm characteristics, notably financial performance, innovation and marketing activities, characteristics of CEOs and employees. As we focus on reverse knowledge spillovers received by foreign firms, our final sample is an unbalanced panel which consists of 2,514 firm-year observations of foreign firms ${ }^{2}$.

\section{Dependent variables}

In this study, we examine the impact of reverse knowledge spillovers on two types of performance for foreign firms: innovation performance and financial performance. Innovation performance is measured with Patents Per Employee which is the total number of patents obtained by a firm in a year divided by its total number of employees (Henderson and Cockburn 1996). Financial performance is measured with Relative Profitability which is defined as the ranking of a firm's return on assets in its industry (Buzzell and Gale 1987). We first rank return on assets of a firm $\left(R O A_{-} r_{a n k_{i}}\right.$ ) with all firms in the same industry $(\mathrm{j})$, then divide the ranking by the number of firms in the industry $\left(N_{j}\right)$, and then use 1 minus the ranking to let a higher value reflect better relative profitability $\left(R P=\left(1-R O A_{-} \operatorname{rank}_{i} / N_{j}\right)\right)$. In this regard, relative financial performance defines how well a firm is positioned with respect to its competitors (Hansen and Wernerfelt 1989) ${ }^{3}$. Maintaining and sustaining competitive advantage involves strategic decisions regarding what activities and technologies a firm should invest in relative to investments by its competitors. Hence, the concept of relative financial performance is a highly relevant proxy for firms in high-tech industries where competition is very intense (Agarwal et al. 2004).

\footnotetext{
${ }^{1}$ Statistics for ZSP comes from "Zhongguancun Index 2011" (http://www.zgc.gov.cn/fzbg/sjbg/), while statistics for Silicon Valley comes from "Silicon Valley Index 2011" (http://www.siliconvalleyindex.org/).

${ }^{2}$ The number of firm-year observations is an expression indicating the total number of observations in panel data involving repeated observations of the sample firms over time.

${ }^{3}$ For example, for an industry with 100 firms, a foreign firm with relative profitability value of 0.65 (mean of the sampled firms) means it ranks 35 among these 100 firms $(0.65=(1-35 / 100))$.
} 


\section{Independent variables}

We use two variables to measure the role of returnees in facilitating knowledge spillovers from local firms to foreign firms. First, we define Returnee $C E O$ as a dummy variable which is coded as 1 if the 'legal representative' of a foreign invested firm is a returnee, and 0 otherwise ${ }^{4}$. This proxy enables us to examine the impact of returnees as firm leaders on reverse knowledge spillovers from local sources and helps to capture the impact of the socio-cultural aspect of embeddedness through individuals by controlling other characteristics of the sample firms in our estimations. In our sample, 17 percent of CEOs in foreign firms are returnees. Second, we proxy the roles of returnees other than those who are CEOs in foreign firms with a count variable of Number of Returnee Employees which is measured as the total number of returnees minus one if the $\mathrm{CEO}$ of the focal firm is a returnee. Excluding returnee CEOs from the proxy enables us to examine the roles of returnee employees other than those who are firm leaders in hypothesized relationships.

The reverse technological and marketing spillovers from local firms were measured by the marketing and technology intensities of local firms in an industry. Reverse Technological Spillovers are measured with R\&D expenditure to the total sales ratio of local firms in the industry in which the focal foreign firms operate. Reverse Marketing Spillovers are measured with sales expenditure to total sales ratio of local firms in the industry in which the focal foreign firms operate.

We control for other characteristics of the sample firms which may affect firm innovation and financial performance. First, it is well established in the literature that a firm's marketing and technology capabilities affect its financial and innovation performance (Im and Workman 2004; Yam, et al. 2011; Zhou and Wu 2010). Sales Expenditure per Employee is used to measure a firm's marketing capability. R\&D Expenditure per Employee is used to measure a firm's innovation capability. Second, previous studies have highlighted the important role of business groups in emerging markets (Hoskisson et al. 2000; Khanna and Yafeh 2007). To take this effect into account, we control for Business Group Affiliation, which is coded as 1 if a firm is affiliated with a business group, and 0 otherwise. Third, previous studies have shown that the characteristics of managers have an important impact on firm performance (e.g., Amason et al. 2006). We control for CEO education which is measured as the number of years of formal education that a CEO experienced. Following Hamori and Koyuncu (2011), we assume that CEOs who hold a college diploma, bachelor degree, master degree, and $\mathrm{PhD}$ degree had 14, 16, 18, and 21 years of formal education, respectively. Fourth, we also control Firm Age (defined as the number of years since firm establishment) and CEO Tenure (defined as the number of years since a CEO took office) in order to take account of the time dimension of local embeddedness as prior

\footnotetext{
${ }^{4}$ According to China's 'General Principles of the Civil Law' (Article 38), a firm's legal representative is the responsible person who acts on behalf of the firm in exercising its functions and powers (Li et al., 2012, p. 258).
} 
studies identified (Najafi-Tavani, Giroud \& Sinkovics 2012). Fifth, we control for Firm Size which is measured as the logarithm of the total number of employees in a firm. Finally, industry structure may influence the competitive landscape of high-tech firms. Thus, we control for industry concentration ratio measured by Herfindahl-Hirschman Index (HHI) and a series of 2-digit industry dummies.

\section{Summary statistics and methods of analyses}

Table 1 presents summary statistics of dependent and independent variables (with the exception of industry dummies). Reverse Technological Spillover is positively and significantly correlated with innovation performance of the sample firms, while Reverse Marketing Spillover is positively and significantly correlated with both firm innovation and financial performance, revealing foreign firms may benefit from knowledge spillovers from local firms. Summary statistics reported in Table 1 also show some typical features of high-tech new ventures. For example, firms in the sample have 1.58 approved patents per 100 employees each year. CEOs of the sample firms spent over 17 years in formal education, which means that they received formal education higher than college level (16 years). In terms of firm size, the average number of employees of the sample firms is about 27 , with the maximum value of 4,675 and the minimum value of 4 . In addition, the average firm age is 4.94, and the average value of CEO tenure is 3.96 years.

To adopt an appropriate modeling strategy to analyze the data, we investigate differences in key characteristics between the sample firms with returnee CEOs and those without returnee CEOs. The results presented in Table 2 show that firms with returnee CEOs have almost two times (198.2\%) higher patent value per employee (statistically significant at 0.001 level) and are $56.4 \%$ more profitable relatively (though only statistically marginal significant at 0.07 level) than those without returnee CEOs. This group of firms also spends $14.0 \%$ less on marketing, but $7.4 \%$ more on R\&D per employee than those without returnee CEOs. In addition, returnee-led firms are $26.3 \%$ younger, $9.5 \%$ smaller and less likely to be affiliated to business groups comparing to their counterparts. The differences provide preliminary evidence which confirms our arguments that returnee CEOs play important roles in foreign firms, but also raises a concern about the possibility that foreign firms' decisions to appoint returnees as CEOs and hire returnee employees may be endogenous. To alleviate this concern, we run Heckman two-stage models (Heckman, 1979). In the first stage, Probit models predict the probability that a foreign firm has a returnee CEO and returnee employees. The independent variables in the first stage Probit models include those firm level variables that have significant values for foreign firms with and without returnee CEOs reported in Table 2. The inverse Mills ratios are introduced in the second stage estimations of the impact of returnee CEOs and returnee employees on reverse knowledge spillovers.

In the second stage of Heckman models, we choose random-effects models over fixed-effects models because the latter require a significant variation in the explanatory variables over time (Judge et al. 1985). Some of our key 
independent variables, such as Returnee $C E O$, are time-invariant and there is only a limited temporal variation during the sample period. In contrast to fixed-effects models, random-effects models allow the estimation of the impact of time-invariant variables. In addition, fixed-effects models generate biased estimates for a short sample period like ours, whereas random-effects models allow the derivation of efficient estimators that make use of both within and between (group) variations and provide better estimates in this case (Heckman 1981). Thus, we estimate random-effects specifications using xtreg in Stata version 11 at the second stage of analyses.

Another concern relating to spillover analyses is endogeneity in industry choice for foreign firms when they made investment decisions in emerging markets. That is, when the productivity of a given industry in an emerging market is high, many foreign firms in that industry will find the emerging market an attractive location (Zhang et al., 2010). To deal with the endogeneity problem, we adopt Hausman tests (Wooldridge 2002) to assess the extent to which local technology intensity and marketing intensity are endogenous. We choose an instrumental variable - one year lagged number of foreign firms in an industry - which has no direct effect on our dependent variables but may be associated with the potentially endogenous independent variable (Zhang et al., 2010). This test addresses the possibility of spillover effect from foreign firms to local firms. In step one, we regress local marketing/technology intensities (i.e. reverse knowledge spillovers from local firms) on the instrumental variable. In step two, we include the residual term from step one into the main econometric specification, and test the null hypothesis that the parameter estimated for the residual is zero. We found that the estimates for the residuals derived in step one are not significantly different from zero, suggesting that endogeneity is not a problem in our estimations.

\section{Results}

We report the results of returnee CEOs' roles in facilitating reverse technological and marketing spillovers from local firms to foreign firms in Table 3. The inverse Mills ratios generated from first stage regressions are insignificant in the second stage models, indicating the selection bias (caused by endogenous decision of hiring returnee CEOs) is not a primary concern. Results in Columns 1-3 and Columns 4-6 are for technological spillovers and marketing spillovers, respectively. Coefficients of Returnee CEO in all six columns are positive and are marginally significant at 0.1 level except for Column 3. The results reveal that returnee CEOs have a positive impact on the innovation and financial performance of foreign firms. The coefficient of Reverse Technological Spillovers in Columns 2 and 3 is statistically insignificant, showing that Hypothesis 1 is not supported. The coefficients of Reverse Marketing Spillovers in Columns 5 and 6 are positive but only marginally significant at 0.1 level in Column 5 , The results reveal that Hypothesis 2 receives partial support only. The coefficient of the interaction between Returnee CEO and Reverse Technological 
Spillovers in Column 3 and the coefficient of the interaction between Returnee CEO and Reverse Marketing Spillovers in Column 6 are both positive and statistically significant at 0.05 level. The significant coefficients of the interaction terms imply that reverse technology and marketing spillovers have significant impacts on the innovation and financial performance of foreign firms when returnee CEOs present in these focal foreign firms. Thus, Hypotheses $3 \mathrm{a}$ and $3 \mathrm{~b}$ are supported. Interestingly, putting insignificant results on the direct impact of reverse spillovers together with significant results on the interaction effects between Returnee $C E O$ and reverse spillovers shows that foreign firms benefit from reverse technological and marketing spillovers from local firms only when returnee CEOs are present in these focal foreign firms. In other words, reverse technological and marketing spillovers from local firms do not affect all foreign firms equally. Only foreign firms with returnee CEOs are able to benefit from local knowledge spillovers.

We compare the effect sizes of our independent variables and interaction terms with benchmarks set in Cohen (1998) and average values in existing international business (IB) and management studies (Ellis 2010; Zhan 2013). First, Columns 1-3 in Table 3 show that the coefficients of Returnee CEO are 1.354, 1.349, and 1.021, respectively. These unstandardized coefficients imply that the mean of patents per employee for foreign firms with returnee CEOs are higher than that for foreign firms without returnee CEOs. One way to interpret these effects is to calculate Cohen's $\mathrm{d}$, which is the standardized difference in mean distance between the two groups of firms (Cohen 1988). Dividing the mean by the standard deviation of the full sample generates the effect size of $0.102(\mathrm{~d}=1.354 / 13.32), 0.102$ $(\mathrm{d}=1.349 / 13.32)$ and $0.076(\mathrm{~d}=1.021 / 13.32)$, respectively. Similar calculations based on the coefficients of Returnee CEO in Columns 4-6 of Table 3 show that effect sizes of Returnee CEO on the relative profitability of foreign firms are $0.107(d=0.38 / 3.54), 0.106(d=0.374 / 3.54)$ and $0.101 \quad(d=0.359 / 3.54)$, respectively. According to Cohen's (1988) recommended benchmarks, the effect sizes we observed for Returnee CEO are about half of the threshold for a small class $(0.20 \leq \mathrm{d}<0.50)$. However, some recent studies on the practice of effect size reporting in multiple disciplines encourage scholars to compare effect size in their studies with findings in the same field instead of a fixed benchmark as proposed in Cohen (1988) because effect sizes may vary across disciplines (Aguinis, 2010; Ellis, 2010). Comparing with the average effect sizes in existing IB studies (Ellis, 2010) and psychology studies (Aguinis, 2005), which are also about half of the benchmark defined by Cohen (1988), we propose that the impact of returnee CEOs on firm performance is of similar economic significance as in other IB studies (Ellis, 2010).

Second, the different meanings of economic significance and statistical significance imply that the results may be economically meaningful even when coefficients are statistically insignificant (Ellis, 2010). In our case, although the direct impact of reverse technological and marketing spillovers is statistically insignificant, we need to investigate their economic significance. To do this, we rely on a partial correlation coefficient which represents the change in the dependent variable when an independent variable is changed by one unit while controlling for all the other independent 
variables. Our calculation shows that the partial correlation coefficients of Reverse Technological Spillovers are 0.054 and 0.034 in Columns 2-3 of Table 3, respectively. The partial correlation coefficients of Reverse Marketing Spillovers are 0.044 and 0.031 in Columns 5-6, respectively. Again, these values are below Cohen's (1988) recommended threshold for a small effect, but close to the average value of 0.06 in existing IB research (Ellis, 2010).

Third, although the interactions between Returnee CEO and Reverse Technological Spillovers and Reverse Marketing Spillovers in Columns 3 and 6 are all statistically significant, we need to measure the economic significance of the interaction terms to provide a sufficient base for drawing a conclusion that Hypotheses $3 \mathrm{a}$ and $3 \mathrm{~b}$ are supported. The coefficients of the interactions in Columns 3 and 6 of Table 3 indicate the difference in the slope of innovation and financial performance on reverse technological and marketing spillovers between the two subgroups of foreign firms with and without returnee CEOs. The coefficient of 0.525 in Column 3 implies that, given the level of reverse technological spillover effect, on average, foreign firms with returnee CEOs have 0.525 more patents than foreign firms without returnee CEO. Considering the mean value of Patent per Employee for foreign firms without returnee CEOs is 1.183 , this means that foreign firms with returnee CEOs benefit $44.4 \%(0.525 / 1.183=0.444)$ more from reverse technology spillovers than foreign firms without returnee CEO. Calculating the coefficient between reverse marketing spillovers and Returnee CEO reveals that foreign firms with returnee CEOs benefit $16.3 \%(0.096 / 0.59=0.163)$ more from reverse marketing spillovers than those without returnee CEOs. Although there is no recommended threshold for the interpretation of interaction coefficients, a $44.4 \%$ conditional difference in the impact on innovation performance and a $16.3 \%$ conditional difference in the impact on financial performance quantitatively imply that Returnee CEO is an important moderating factor on the relationship between reverse technological and marketing spillovers and firm performance. Thus, we conclude that the role of returnee CEOs in facilitating reverse spillovers has both statistical and economic significance.

Although a CEO has probably the most important impact on firm performance, returnees in non-CEO positions or returnee employees may also play an important role in facilitating reverse spillovers from local firms to foreign firms. Thus, we test hypotheses using the Number of Returnee Employees as an alternative proxy of returnees and report the results in Table 4. The results in Table 4 are similar to those in Table 3. One difference is that Number of Returnee Employees is not significantly associated with innovation and the financial performance of foreign firms, implying that non-CEO returnees may have a less significant (although positive) impact on the performance of foreign firms in an emerging market. Similar to the results in Table 3, direct effects of reverse technological and marketing spillovers are statistically insignificant, while the interaction effects between returnee employees and reverse spillovers are statistically significant (Columns 3 and 6 in Table 4). Effect size analyses for the coefficients in Table 4 draw a similar conclusion to those in Table 3. The results using returnee employees as an alternative proxy are consistent with those 
using the dummy variable of Returnee CEO, confirming that reverse technological and marketing spillover effects are stronger when returnees are present in foreign firms.

\section{Discussion}

This study examines whether foreign firms are able to benefit from reverse knowledge spillovers when operating in China and whether the presence of returnees in foreign firms enhances the impact of reverse knowledge spillovers from local firms. Differing from existing studies which have mainly focused on knowledge spillovers from foreign firms to local firms when they operate in a developing country (Blalock and Simon 2009; Blomstrom and Kokko 1998; Buckley et al. 2002; Keller and Yeaple 2003; Liu and Wang 2003), our research responds to a recent call for studying reverse innovation from emerging economies to the West (Govindarajan and Ramamurti 2011; Sarka 2011) and has examined whether the recent development of Chinese firms and their technological upgrading represent potential opportunities for foreign firms to benefit from reverse knowledge spillovers. Specifically, we have investigated the relationship between two types of reverse spillovers, including technological spillovers and marketing spillovers, and the innovation and financial performance of foreign firms. Proposing a new channel for reverse knowledge spillovers, we have focused on the role of returnees in reverse knowledge spillovers. We extend the existing literature on international knowledge spillovers by considering returnees a unique channel for bridging knowledge gaps in different knowledge contexts.

Our findings show that the relationship between reverse knowledge spillovers and firm performance becomes much stronger in the presence of returnees. These findings suggest that knowledge is embedded in social structure (Kogut and Zander 1992; Meyer 2007). Hence, obtaining external knowledge requires socio-cultural embeddedness in local environments, and interaction with local firms. This aspect has largely been overlooked in prior literature on FDI spillovers based on secondary data analysis. Moreover, complex knowledge is 'sticky' even within tight social networks (Sorenson et al. 2006) so returnees in foreign firms act as boundary spanners and help to reduce barriers to the absorption of external knowledge. In particular, they may help foreign firms to overcome the liabilities of foreignness (Raab and Ambos 2008; Zaheer 1995). Our results imply that having local presence and developing local linkages may be necessary conditions, but not sufficient conditions, for reverse knowledge spillovers. The real effect of embeddedness is attached to managers and employees who have special characteristics. In our case, acting as boundary spanners, returnees are able to connect foreign firms with local firms more effectively due to their socio-cultural embeddedness. Our findings draw particular attention to the social dimensions of knowledge spillovers, especially the socio-cultural embeddedness of managers and employees whose special characteristics play an important role in reverse knowledge spillovers. 
By focusing on returnees in reverse knowledge flows, our study helps to advance research on FDI spillovers by emphasizing the social aspect of knowledge flows and how returnees help to overcome barriers to knowledge spillovers. This aspect has been underexplored theoretically and empirically. In particular, we highlight the fact that research on FDI spillovers should move away from focusing on the technical capability of recipient firms, such as internal knowledge stock, to focus more on the social aspects of knowledge spillovers. We propose that the socio-cultural embeddedness of employees/managers should be incorporated into research on cross-border knowledge spillovers in order to reflect the impact of internationally mobile individuals, such as returnees.

In addition to the impact of returnees, our research also moves beyond the traditional focus on knowledge spillovers from foreign firms to local firms in emerging economies and examines whether the technological catch-up of emerging economy firms has implications for technological leaders in terms of the direction of knowledge flows. The findings add valuable empirical evidence and highlight the need to pay more attention to reverse knowledge spillovers from local firms to foreign firms that operate in emerging economies. Our research helps to provide a more complete account of knowledge exchanges between local and foreign firms in an emerging economy.

Finally, we have moved beyond the measures of embeddedness adopted in existing literature by considering the impact of the cultural advantages of actors. Existing studies in general, and survey based studies in particular, tend to measure the relationships between foreign and local firms through partnership, or the relationships with local suppliers and buyers at firm level (Najafi-Tavani et al. 2012; Scott-Kennel 2007). Such measures tend to overlook the cultural dimension of embeddedness at an individual level. Our study bridges the gap between firm level and individual level by capturing the impact of returnee CEOs and returnee employees on knowledge flows and provides new insights into cultural embeddedness.

Our findings have important policy and managerial implications. First, the results can help policy makers to gain a deeper understanding of the implications of the rapid development of Chinese firms. The transformation of Chinese firms not only represents intensified competition but also potential benefits for foreign firms through reverse knowledge spillovers. The governments can create a broader platform for encouraging firms to engage in international cooperation, and learn from Chinese firms. Second, the findings raise awareness of reverse knowledge spillovers and the importance and availability of internationally mobile talents. The positive moderating effect of returnees on reverse knowledge flows implies that foreign firms should fully exploit the unique advantages associated with returnees in emerging economies. Such individuals can help to bridge knowledge gaps between foreign firms and local firms, and help to enhance the performance of foreign firms.

Our study has a number of limitations. First, the sample firms were based in a single science park in the Chinese context. Further research should extend this line of research to other emerging economies, such as India and 
Russia. Second, while we have exploited data availability in relation to returnees in order to address an important research question concerning whether returnees enhance the impact of reverse knowledge flows between foreign firms and local Chinese firms, our proxy of returnee representatives is rather simplistic due to the use of secondary data, though our panel data helps to capture the time dimension of local embeddedness of foreign firms. In addition, we were unable to consider the impact of other returnees in key managerial positions, such as marketing and technology executives, although we have obtained similar results using the number of returnees as a proxy. Future research is needed to reveal how returnees affect knowledge exchanges between local and foreign firms. In particular, we call for more qualitative studies in order to unpack the process of reverse knowledge spillovers in the presence of returnees, and further compare the differing impacts of returnee CEOs and returnee employees. Finally, we were unable to examine the impact of the local experience of returnees due to the availability of the data, although we controlled for the tenure of returnee representatives. It would be interesting to examine whether the local experience of returnees helps to strengthen the impact of reverse knowledge spillovers from local firms to foreign firms.

\section{Conclusion}

This paper has analysed whether there is reverse knowledge spillovers from local firms to foreign firms based on sample firms in ZSP in Beijing. Adopting the knowledge-based perspective and embeddedness theory, we found that the presence of returnees in foreign firms enhances the impact of technological spillovers and marketing spillovers on the performance of foreign firms in China. Our study highlights the importance of the social aspects of inter-firm knowledge flows across international boundaries and provides new insight into social dimensions of reverse knowledge spillovers in an emerging economy.

\section{Acknowledgements}

Financial support from the Economic and Social Research Council (RES-238-25-0027) and the National Natural Science Foundation of China (\#71172020) is gratefully acknowledged. The authors would like to thank two anonymous reviewers for their constructive comments on an earlier version of the paper.

\section{References}

Agarwal, R., Echambadi, R., Franco, A. M., \& Sarkar, M. (2004). Knowledge transfer through inheritance: Spin-out generation, development, and survival. Academy of Management Journal, 47(4), 501-522.

Aguinis, H., Beaty, J. C., Boik, R. J., \& Pierce, C. A. (2005). Effect size and power in assessing moderating effects of categorical variables using multiple regression: a 30-year review. Journal of Applied Psychology, 90(1), 94107. 
Aguinis, H., Werner, S., Abbott, J. L., Angert, C., Park J. H., \& Kohlhausen, D. (2010). Customer-centric science: Reporting significant research results with rigor, relevance, and practical impact in mind. Organization Research Methods, 13(3), 515-539.

Ahuja, G., Lampert, M. C., \& Tandon, V. (2008). Chapter 1: Moving beyond Schumpeter: management research on the determinants of technological innovation. Academy of Management Annals, 2(1), 1-98

Allen, T. (1990). People and technology transfer. WP\# 3201-90BPS. Massachusetts Institute of Technology.

Amason, A. C., Shrader, R. C., \& Tompson, G. H. (2006). Newness and novelty: Relating top management team composition to new venture performance. Journal of Business Venturing, 21(1), 125-48.

Anand, J. (2002). Resource deficits and international entry mode: analysis of context-specificity and fungibility of resources. Advances in International Comparative Management, 14(6), 155-72.

Arrow, K. J. (1962). The economic implications of learning by doing. Review of Economic Studies, 29(3), $155-173$.

Beckert, J. (2003), Economic sociology and embeddedness: How shall we conceptualize economic action? Journal of Economic Issues, 37(3), 769-787.

Blalock, G., \& Simon, D. (2009). Do all firms benefit equally from downstream FDI? The moderating effect of local suppliers' capabilities on productivity gains. Journal of International Business Studies, 40(7), 1095-1112.

Blomstrom, M., \& Kokko, A. (1998). Multinational corporations and spillovers. Journal of Economic Surveys, 12(3), $247-277$.

Bonache, J., \& Brewster, C. (2001). Knowledge transfer and the management of expatriation. Thunderbird International Business Review, 43(1), 145-168.

Bouty, I. (2000). Interpersonal and interaction influences on informal resource exchanges between R\&D researchers across organizational boundaries. Academy of Management Journal, 43(1), 50-65.

Bresman, H., Birkinshaw, J., \& Nobel, R. (2010). Knowledge transfer in international acquisitions. Journal of International Business Studies, 41(1), 5-20.

Bruche, G. (2009). The emergence of China and India as new competitors in MNCs innovation networks. Competition \& Change, 13(3), 267-288.

Buckley, P., Carter, M., Clegg, J., \& Tan, H. (2005). Language and social knowledge in foreign-knowledge transfer to China. International Studies of Management \& Organization, 35(1), 47-65.

Buckley, P., \& Carter, M.J. (1996). The economics of business process design: Motivation, information and coordination within the firm. International Journal of the Economics of Business, 3(1), 5-25.

Buckley, P., Clegg, J., \& Wang, C. (2002). The impact of inward FDI on the performance of Chinese manufacturing firms. Journal of International Business Studies, 33(4), 637-655.

Buzzell, R. D., \& Gale, B. T. (1987). The PIMS (Profit Impact of Market Strategy) Principles: Linking Strategy to Performance. New York: Free Press.

Cantwell, J, and Mudambi, R. (2011). Physical attraction and the enterprise. Global Strategy Journal, 1(3/4), $206-232$.

Casson, M. (2003). The Entrepreneur: An Economic Theory ( $2^{\text {nd }}$ edition). Cheltenham: Edward Elgar.

Caves, R.E. (1974). Multinational firms, competition and productivity in host-country markets. Economica, 41(162), 176-193

Child, J., \& Rodrigues, S. (1996). The role of social identity in the international transfer of knowledge through joint ventures. In Clegg, S.R. and Palmer, G. (Eds), The Politics of Management Knowledge. London: Sage.

Choudhury, P. (2010). Knowledge creation in multinationals and return migration: Evidence from micro data, Academy of Management Best Papers Proceedings

Coe, D. \& Helpman, E. (1995). International R\&D spillovers. European Economic Review, 39(5), 859-887.

Cohen, J. (1988). Statistical Power Analysis for the Behavioral Sciences (2nd ed.). Hillsdale, NJ: Erlbaum.

Cohen, W., \& Levinthal, A. (1990). Absorptive capability: the new perspective learning and innovation. Administrative Science Quarterly, 35(1), 128-152.

David, P., \& Rosenbloom, J. (1990). Marshallian factor market externalities and the dynamics of industrial location, Journal of Urban Economics, 28(3), 349-370.

Eapen, A. (2012). Social structure and technology spillovers from foreign to domestic firms. Journal of International Business Studies, 43(3), 244-263.

Eden, L. (2009). Reverse knowledge transfers, culture clashes and going international. Journal of International Business Studies, 40(2), 177-180.

Ellis, P. D. (2010). Effect sizes and the interpretation of research results in international business. Journal of International Business Studies, 41(9): 1581-88.

Ensign, D., \& Hébert, L. (2009). Competing explanations for knowledge exchange: Technology sharing within the globally dispersed R\&D of the multinational enterprise. Journal of High Technology Management Research, 20, 75-85.

Ensign, D., \& Hébert, L. (2010). How reputation affects knowledge sharing among colleagues. MIT Sloan Management Review, 50(2): 78-81.

Fang, Y., Jiang, G., Makino, S., \& Beamish, P. (2010). Multinational firm knowledge, use of expatriates, and foreign subsidiary performance. Journal of Management Studies, 47(1), 27-54.

Fredric, K., Noel J. L., \& Aviv, S. (2006). Entrepreneurial, market, and learning orientations and international 
entrepreneurial business venture performance in South African firms, International Marketing Review, 23(5), 504-523.

Frost, T., Birkinshaw, J., \& Ensign, J. (2002). Centers of excellence in multinational firms. Strategic Management Journal, 23(11), 997-1018.

Gong, Y., \& Girma, S. (2008). FDI, linkages and the efficiency of state-owned enterprises in China, Journal of Development Studies, 4(5), 728-749.

Govindarajan, V. \& Ramamurti, R. (2011). Reverse innovation, emerging markets, and global strategy. Global Strategy Journal, 1(3/4), 191-205.

Granovetter, M. (1985). Economic action and social structure: The problem of embeddedness. American Journal of Sociology, 91, 481-510.

Grant, R. M. (1996). Toward a knowledge-based theory of the firm. Strategic Management Journal, 17, 109-22.

Griffith, R., \& Miller, H. (2011), Innovation in China: the rise of Chinese inventors in the production of knowledge. IFS Working Paper W11/15.

Gupta, A. K. \& Govindarajan, V. (2000). Knowledge flows within multinational corporations. Strategic Management Journal, 21(4), 473-496.

Hansen, G. S., \& Wernerfelt, B. (1989). Determinants of firm performance: The relative importance of economic and organizational factors. Strategic Management Journal, 10(5), 399-411.

Hamori, M., \& Koyuncu, B. (2011). Career advancement in large organizations in Europe and the United States: Do international assignments add value? International Journal of Human Resource Management, 22(4), 843-62.

Harzing, A., Koster, K., \& Magner, U. (2011). Babel in business: The language barrier and its solutions in the HQsubsidiary relationship. Journal of World Business, 46(3), 279-287.

Heckman, J. J. (1979). Sample selection bias as a specification error. Econometrica, 47(1), 153-161.

Heckman, J. J. (1981). 'Statistical models for discrete panel data'. In C. F. Manski and D. McFadden (eds.), Structural Analysis of Discrete Data with Econometric Applications. MIT Press, Boston, MA, pp. 114-178.

Henderson, R., \& Cockburn, I. (1996). Scale, scope, and spillovers: the determinants of research productivity in drug discovery. The Rand Journal of Economics, 27(1), 32-59.

Hoskisson, R. E., Eden, L., Lau, C. M., \& Wright, M. (2000). Strategy in emerging economies. Academy of Management Journal, 43(3), 249-67.

Im, S., \& Workman, J.P. (2004). Market orientation, creativity, and new product performance in high-technology firms. Journal of Marketing, 68, 114-32.

Inkpen, A. C., \& Beamish, P.W. (1997). Knowledge, bargaining power and the instability of international joint ventures. Academy of Management Review, 22(1), 177-202

Jones, C., Hesterly, W.S. \& Borgatti, S. P. (1997). A general theory of network governance: exchange conditions and social mechanisms. Academy of Management Review, 22(4), 911-945.

Judge, G., Griffiths, W., Hill, C., \& Lee, T. C. (1985). The Theory and Practice of Econometrics. New York: Wiley.

Keller, W., \& Yeaple, S. (2003). Multinational enterprises, international trade, and productivity growth: firm level evidence from the United States. NBER Working Papers No. 9504.

Khanna, T., \& Yafeh, Y. (2007). Business groups in emerging markets: Paragons or parasites? Journal of Economic Literature, 45(2), 331-372.

Kogut, B., \& Zander, U. (1992). Knowledge of the firm, combinative capabilities, and the replication of technology. Organization Science, 3(3), 383-397.

Lane, P.J., Koka, B.R., \& Pathak, S. (2006). The reification of absorptive capacity: a critical review and rejuvenation of the construct. Academy of Management Review, 31(4), 833-863.

Li, H., Zhang, Y., Li, Y., Zhou, L., \& Zhang, W. (2012). Returnees versus locals: Who performs better in China's technology entrepreneurship? Strategic Entrepreneurship Journal, 6(3), 257-272.

Liu, X., \& Wang, C. (2003). Does foreign direct investment facilitate technological progress: evidence from Chinese industries? Research Policy, 32(6), 945-953.

Liu, X. \& Buck, T. (2007). Innovation performance and channels for international technology spillovers: Evidence from Chinese high-tech industries, Research Policy, 36(3), 355-366.

Liu, X., Wright, M., Filatotchev, I., Dai, O., \& Lu, J. (2010). Human mobility and international knowledge spillovers: Evidence from high-tech small and medium enterprises in an emerging Market. Strategic Entrepreneurship Journal, 4(4), 340-355.

Lucas, R. E. (1988). On the mechanics of economic development. Journal of Monetary Economics, 22(1), 3-42.

Macneil, I. (1980). The New Social Contract. Yale University Press: New Haven, CT.

Macneil, I. (1999). Relational contract theory: challenges. Working Paper, Northwestern University School of Law.

Makino, S., \& Delios, A. (1996). Local knowledge transfer and performance: implications for alliance formation in Asia. Journal of International Business Studies, 27(5), 905-27.

Makino, S. \& Inkpen, A. (2003). Knowledge seeking FDI and learning across borders. In M. Easterby-Smith \& M. A. Lyles (Eds.), The Blackwell Handbook of Organizational Learning and Knowledge Management: 233-252. Oxford: Blackwell Publishers. 
Marin, A. \& Bell, M. (2006). Technology spillovers from foreign direct investment: the active role of MNC subsidiaries in Argentina in the 1990s. Journal of Development Studies, 4, 678-697.

Meyer, K. (2007). Contextualizing organizational learning: Lyles and Salk in the context of their research. Journal of International Business Studies, 38(1), 27-37.

Najafi-Tavani, Z, Giroud, A., \& Sinkovics, R. (2012). Mediating effects in reverse knowledge transfer processes. Management International Review, 52: 461-488.

Nohria N., \& Eccles R. G. (1992). Networks and Organizations: Structure, Form, and Action. Boston, MA: Harvard University Press.

Nonaka, I. (1994). A dynamic theory of organizational knowledge creation. Organization Science, 5(1), 14-37.

Nonaka, I., \& Takeuchi, H. (1995). The Knowledge Creating Company: How Japanese Companies Create the Dynamic of Innovation. New York: Oxford University Press.

Obukhova, E. (2011). Experience vs. legitimacy: returnees and political ties in China. SSRN Working Paper.

Prahalad C. K. (2005). The Fortune at the Bottom of the Pyramid. Philadelphia, PA.: Wharton School Publishing.

Raab, K. J., \& Ambos, B. (2008). Isolation and separation in teams: An analysis of configurations and their impact on knowledge flows. Strategic Management Society Meeting, Cologne.

Reagans, R., \& McEvily, B. (2003). Network structure and knowledge transfer: The effects of cohesion and range. Administrative Science Quarterly, 48(2), 240-267.

Romer, P. (1994). The origins of endogenous growth. Journal of Economic Perspectives, 8(1), 3-22.

Sarkar M. B. (2011). Moving forward by going in reverse: Emerging trend in global innovation and knowledge strategies. Global Strategy Journal, 1(3/4), 237-242.

Saxenian A. (2006). The New Argonauts: Regional Advantage in a Global Economy. Harvard University Press: Cambridge, MA.

Scott-Kennel, J. (2007). Foreign direct investment and local linkages: An empirical investigation, Management International Review, 47(1), 51-77.

Sorenson, O., McEvily, S., Ren, C. R., \& Roy, R., (2006). Niche width revisited: Organizational scope, behavior and performance. Strategic Management Journal, 27(10), 915-36.

Spencer, J. W. (2008). The impact of multinational enterprise strategy on indigenous enterprises: Horizontal spillovers and crowding out in developing countries. Academy of Management Review, 33(2), 341-361.

Szulanski, G., Cappetta, R., \& Jensen, R. (2004). When and how trustworthiness matters: Knowledge transfer and the moderating effect of causal ambiguity. Organization Science, 15(5), 600-613.

Tan, J. (2006). Growth of industry clusters and innovation: Lessons from Beijing Zhongguancun science park, Journal of Business Venturing, 21(6), 827-850.

Tian, X. (2007). Accounting for sources of FDI technology spillovers: Evidence from China. Journal of International Business Studies, 38(1), 147-159.

Todo, Y., Zhang, W., \& Zhou, L. A. (2011). Intra-industry knowledge spillovers from foreign direct investment in research and development: evidence from China's 'Silicon Valley. Review of Development Economics, 15, 569585.

Tung, R. L. (2008). Brain circulation, diaspora, and international competitiveness. European Management Journal, 26(5), 298-304.

UNESCO (2012). A global perspective on science and technology (S\&T), Available at http://www.uis.unesco.org/ScienceTechnology/Pages/default.aspx. Accessed on 4 July 2012.

Uzzi, B., \& Gillespie, J. (2002). Financial networks: Embeddedness and the firm's debt performance. Strategic Management Journal, 23(7), 595-618.

Wei, Y. \& Liu, X. (2006). Productivity spillovers from R\&D, exports and FDI in China's manufacturing sector. Journal of International Business Studies, 37(4), 544-57.

Wei, Y., Liu, X., \& Wang, C. (2008). Mutual productivity spillovers between foreign and local firms in China. Cambridge Journal of Economics, 32(4), 609-631.

Wooldridge, J. M. (2002). Econometric analysis of cross section and panel data. Cambridge, MA: MIT Press.

Yam, R., Lo, W., Tang, E., \& Lau, A. (2011). Analysis of sources of innovation, technological innovation capabilities, and performance: An empirical study of Hong Kong manufacturing industries. Research Policy, 40(3), 737747.

Zaheer, S. (1995). Overcoming the liability of foreignness. Academy of Management Journal, 38(2), $341-363$.

Zhang, Y., Li, H., \& Schoonhoven, C. B. (2009). Intercommunity relationships and community growth in China's high technology industries 1988-2000. Strategic Management Journal, 30(2), 163-183.

Zhang, Y., Li, H., Li, Y., \& Zhou, L.A. (2010). FDI spillovers in an emerging market: The role of foreign firms' country origin diversity and domestic firms' absorptive capacity. Strategic Management Journal, 31, 969-989.

Zhou, K. Z., \& Wu, F. (2010). Technological capability, strategic flexibility, and product innovation. Strategic Management Journal, 31(6), 547-561.

Zou, H., \& Ghauri, P. (2008). Learning through international acquisitions: The process of knowledge acquisitions in China. Management International Review, 48(2), 207-226. 
Table 1: Summary Statistics and Correlations

\begin{tabular}{|c|c|c|c|c|c|c|c|c|c|c|c|c|c|c|c|c|}
\hline & & Mean & S.D. & 1 & 2 & 3 & 4 & 5 & 6 & 7 & 8 & 9 & 10 & 11 & 12 & 13 \\
\hline 1 & Patents per (100) employee & 1.58 & $\begin{array}{l}13.3 \\
?\end{array}$ & & & & & & & & & & & & & \\
\hline 2 & Relative profitability & 0.65 & 3.54 & $0.09 * *$ & & & & & & & & & & & & \\
\hline 3 & Returnee CEO & 0.17 & 0.38 & $0.07 * *$ & $0.04 \dagger$ & & & & & & & & & & & \\
\hline 4 & $\begin{array}{l}\text { Number of returnee } \\
\text { emnlovees }\end{array}$ & 0.45 & 1.19 & 0.02 & 0.02 & $0.13 * *$ & & & & & & & & & & \\
\hline 5 & $\begin{array}{l}\text { Reverse technological } \\
\text { snillovers }\end{array}$ & 1.25 & 0.58 & $0.07 * *$ & 0.01 & $0.08 * *$ & $0.07 * *$ & & & & & & & & & \\
\hline 6 & Reverse marketing spillovers & 0.01 & 0.08 & $0.09 * *$ & $0.05^{*}$ & 0.00 & $0.04 \dagger$ & $0.26^{* *}$ & & & & & & & & \\
\hline 7 & $\begin{array}{l}\text { Sale expenditure per } \\
\text { employee }(\log )\end{array}$ & 2.22 & 1.83 & $-0.04 \dagger$ & 0.00 & $0.07 * *$ & 0.03 & 0.00 & -0.02 & & & & & & & \\
\hline 8 & $\begin{array}{l}\text { R\&D expenditure per } \\
\text { employee (log) }\end{array}$ & 2.81 & 1.57 & $0.09 * *$ & $0.04 \dagger$ & $0.05^{*}$ & $0.10 * *$ & $0.05 *$ & $-0.03 \dagger$ & $0.12 * *$ & & & & & & \\
\hline 9 & Firm age & 4.94 & 3.51 & -0.01 & 0.00 & $-1.15 * *$ & $-\overline{0.07 * *}$ & $-0.07 * *$ & 0.03 & $0.12 * *$ & $-10 * *$ & & & & & \\
\hline 10 & Firm size $(\log )$ & 3.3 & 1.19 & $-0.04 \dagger$ & $0.04 \dagger$ & $-\overline{0.10 * *}$ & $0.25 * *$ & $-0.04 \dagger$ & -0.03 & $0.33 * *$ & $0.06^{* *}$ & $0.20 * *$ & & & & \\
\hline 11 & Business group affiliation & 0.07 & 0.26 & -0.02 & 0.01 & $-\overline{0.07 * *}$ & -0.01 & -0.03 & 0.02 & $0.10 * *$ & 0.03 & $0.08 * *$ & $0.14 * *$ & & & \\
\hline 12 & CEO education & 17.28 & 2.23 & 0.03 & 0.03 & $0.34 * *$ & $0.14 * *$ & 0.02 & 0.02 & 0.02 & $0.09 * *$ & $-0.10 * *$ & 0.00 & 0.02 & & \\
\hline 13 & CEO tenure & 3.96 & 3.16 & 0.00 & $-0.04 \dagger$ & $-\overline{0} 11 * *$ & - & $-0.05^{*}$ & 0.01 & 0.03 & $-0.08 * *$ & $0.75 * *$ & $0.04 \dagger$ & 0.02 & $-\overline{0.08 * *}$ & \\
\hline 14 & Herfindahl index & 0.07 & 0.10 & 0.00 & $0.14 * *$ & $-0.03 \dagger$ & $-0.04 \dagger$ & 0.03 & 0.02 & $0.04 *$ & $-12 * *$ & $0.06 * *$ & $0.04 \dagger$ & $\begin{array}{l}0.07^{*} \\
* \\
\end{array}$ & -0.03 & 0.03 \\
\hline
\end{tabular}

Note: $\dagger, *$, and $* *$ represent statistical significance at $10 \%, 5 \%$ and $1 \%$, respectively. Patents per employee and Technology awards per employee are multiplied by 100 , which means patents per 100 employees. 
Table 2: Differences between foreign firms with and without returnee CEOs

\begin{tabular}{lccrrc}
\hline Key firm characteristics & $\begin{array}{c}\text { Returnee } \\
\text { CEO = } \\
(1)\end{array}$ & $\begin{array}{c}\text { Returnee } \\
\text { CEO =0 }\end{array}$ & $\begin{array}{c}\text { Difference } \\
\text { value }\end{array}$ & $\begin{array}{c}\text { Difference } \\
\text { ratio } \\
(4)\end{array}$ & $\begin{array}{c}\text { p- } \\
\text { value }\end{array}$ \\
\hline Patents per (100) employees & 3.528 & 1.183 & 2.345 & $198.2 \%$ & 0.001 \\
Relative profitability & 0.923 & 0.590 & 0.333 & $56.4 \%$ & 0.077 \\
Sales expenditure per employee & 1.951 & 2.269 & -0.318 & $-14.0 \%$ & 0.001 \\
R\&D expenditure per employee & 2.983 & 2.777 & 0.206 & $7.4 \%$ & 0.014 \\
Firm age & 3.808 & 5.166 & -1.359 & $-26.3 \%$ & 0.000 \\
Firm size & 3.037 & 3.355 & -0.318 & $-9.5 \%$ & 0.000 \\
Business group affiliation & 0.031 & 0.080 & -0.050 & $-61.8 \%$ & 0.000 \\
\hline
\end{tabular}

Note: Columns 1 and 2 report key firm characteristics for the sample firms with and without returnee CEOs, respectively; Column 3 presents differences between values in columns 1 and 2 (column 1 minus column 2); Column 4 shows ratios of differences between values in columns 1 and 2 [(column 1 minus column 2) / column 2]; Column 5 includes p-values of t-tests between columns 1 and 2; Different from other tables in which logarithms of Sales expenditure per employee, R\&D expenditure per employee, Firm size are used, values of these firm characteristics in Table 2 are real values to make the comparison easier to understand. 
Table 3: Results of the second-stage random-effects models on the role of returnee CEOs in reverse technological and marketing spillovers

DV: Patents per (100) DV: Relative profitability

$\begin{array}{lllll}1 & (2) & \text { (3) } & \text { (4) } & \text { (5) }\end{array}$

\begin{tabular}{|c|c|c|c|c|c|c|}
\hline Returnee CEO & $\begin{array}{l}1.354 \dagger \\
(0.767)\end{array}$ & $\begin{array}{l}1.349 \dagger \\
(0.768)\end{array}$ & $\begin{array}{c}1.021 \\
(0.780)\end{array}$ & $\begin{array}{l}0.380 \dagger \\
(0.205)\end{array}$ & $\begin{array}{l}0.374 \dagger \\
(0.205)\end{array}$ & $\begin{array}{l}0.359 \dagger \\
(0.205)\end{array}$ \\
\hline Reverse technological spillovers & & $\begin{array}{c}0.153 \\
(0.803)\end{array}$ & $\begin{array}{l}-0.044 \\
(0.805)\end{array}$ & & & \\
\hline $\begin{array}{l}\text { Returnee CEO * } \\
\text { Reverse technological spillovers }\end{array}$ & & & $\begin{array}{l}0.525 * \\
(0.218)\end{array}$ & & & \\
\hline Reverse marketing spillovers & & & & & $\begin{array}{l}2.164 \dagger \\
(1.141)\end{array}$ & $\begin{array}{c}1.646 \\
(1.162)\end{array}$ \\
\hline $\begin{array}{l}\text { Returnee CEO * } \\
\text { Reverse marketing spillovers }\end{array}$ & & & & & & $\begin{array}{l}0.096^{*} \\
(0.041)\end{array}$ \\
\hline Sales expenditure per employee & $\begin{array}{c}-0.23 \\
(0.719)\end{array}$ & $\begin{array}{l}-0.283 \\
(0.770)\end{array}$ & $\begin{array}{l}-0.335 \\
(0.769)\end{array}$ & $\begin{array}{c}0.048 \\
(0.203)\end{array}$ & $\begin{array}{c}0.122 \\
(0.207)\end{array}$ & $\begin{array}{c}0.119 \\
(0.207)\end{array}$ \\
\hline R\&D expenditure per employee & $\begin{array}{c}0.738 \\
(0.603)\end{array}$ & $\begin{array}{c}0.780 \\
(0.643)\end{array}$ & $\begin{array}{r}0.812 \\
(0.642)\end{array}$ & $\begin{array}{c}0.020 \\
(0.171)\end{array}$ & $\begin{array}{c}-0.04 \\
(0.174)\end{array}$ & $\begin{array}{c}-0.04 \\
(0.174)\end{array}$ \\
\hline Firm age & $\begin{array}{c}0.127 \\
(1.949)\end{array}$ & $\begin{array}{l}-0.015 \\
(2.088)\end{array}$ & $\begin{array}{l}-0.169 \\
(2.085)\end{array}$ & $\begin{array}{c}0.252 \\
(0.555)\end{array}$ & $\begin{array}{c}0.455 \\
(0.565)\end{array}$ & $\begin{array}{c}0.440 \\
(0.564)\end{array}$ \\
\hline Firm size & $\begin{array}{l}-0.259 \\
(3.088)\end{array}$ & $\begin{array}{l}-0.484 \\
(3.307)\end{array}$ & $\begin{array}{l}-0.708 \\
(3.301)\end{array}$ & $\begin{array}{c}0.454 \\
(0.874)\end{array}$ & $\begin{array}{c}0.774 \\
(0.889)\end{array}$ & $\begin{array}{c}0.752 \\
(0.889)\end{array}$ \\
\hline Business group affiliation & $\begin{array}{l}-0.499 \\
(8.037)\end{array}$ & $\begin{array}{l}-1.081 \\
(8.597)\end{array}$ & $\begin{array}{l}-1.626 \\
(8.583)\end{array}$ & $\begin{array}{c}1.119 \\
(2.285)\end{array}$ & $\begin{array}{c}1.925 \\
(2.323)\end{array}$ & $\begin{array}{c}1.860 \\
(2.322)\end{array}$ \\
\hline CEO education & $\begin{array}{l}-0.010 \\
(0.129)\end{array}$ & $\begin{array}{l}-0.010 \\
(0.129)\end{array}$ & $\begin{array}{l}-0.004 \\
(0.129)\end{array}$ & $\begin{array}{c}0.011 \\
(0.034)\end{array}$ & $\begin{array}{c}0.013 \\
(0.034)\end{array}$ & $\begin{array}{c}0.013 \\
(0.034)\end{array}$ \\
\hline CEO tenure & $\begin{array}{l}-0.016 \\
(0.134)\end{array}$ & $\begin{array}{l}-0.017 \\
(0.134)\end{array}$ & $\begin{array}{l}-0.005 \\
(0.134)\end{array}$ & $\begin{array}{l}-0.045 \\
(0.036)\end{array}$ & $\begin{array}{l}-0.045 \\
(0.036)\end{array}$ & $\begin{array}{l}-0.043 \\
(0.036)\end{array}$ \\
\hline Herfindahl index & $\begin{array}{l}-12.939 \dagger \\
(7.840)\end{array}$ & $\begin{array}{c}-13.378 \\
(8.172)\end{array}$ & $\begin{array}{c}- \\
14.352 \dagger \\
(8.169)\end{array}$ & $\begin{array}{l}-1.696 \\
(2.086)\end{array}$ & $\begin{array}{l}-1.466 \\
(2.089)\end{array}$ & $\begin{array}{l}-1.404 \\
(2.087)\end{array}$ \\
\hline Inverse Mills Ratio & $\begin{array}{c}0.28 \\
(8.151)\end{array}$ & $\begin{array}{l}-0.322 \\
(8.740)\end{array}$ & $\begin{array}{l}-0.914 \\
(8.726)\end{array}$ & $\begin{array}{c}0.977 \\
(2.313)\end{array}$ & $\begin{array}{c}1.817 \\
(2.354)\end{array}$ & $\begin{array}{c}1.761 \\
(2.352)\end{array}$ \\
\hline Industry dummy (2-digit) & Y & Y & Y & Y & $\mathrm{Y}$ & $\mathrm{Y}$ \\
\hline Constant & $\begin{array}{c}6.175 \\
(24.109)\end{array}$ & $\begin{array}{c}4.596 \\
(25.491)\end{array}$ & $\begin{array}{c}3.397 \\
(25.450)\end{array}$ & $\begin{array}{c}23.309 * * \\
(6.749)\end{array}$ & $\begin{array}{c}25.455^{* *} \\
(6.840)\end{array}$ & $\begin{array}{c}25.273 * * \\
(6.835)\end{array}$ \\
\hline chi2 & 198.9248 & 198.883 & 204.998 & 363.4818 & 367.2829 & 373.7103 \\
\hline Adjusted R-square & 0.0776 & 0.0776 & 0.0802 & 0.1375 & 0.1388 & 0.1414 \\
\hline $\mathrm{N}$ & 2514 & 2514 & 2514 & 2511 & 2511 & 2511 \\
\hline
\end{tabular}

Note: $(1) \dagger, *$, and $* *$ represent statistical significance at $10 \%, 5 \%$ and $1 \%$, respectively.

(2) The number in the brackets shows standard errors. 
Table 4: Results of the second-stage random-effects models on the role of returnee employees in reverse technological and marketing spillovers

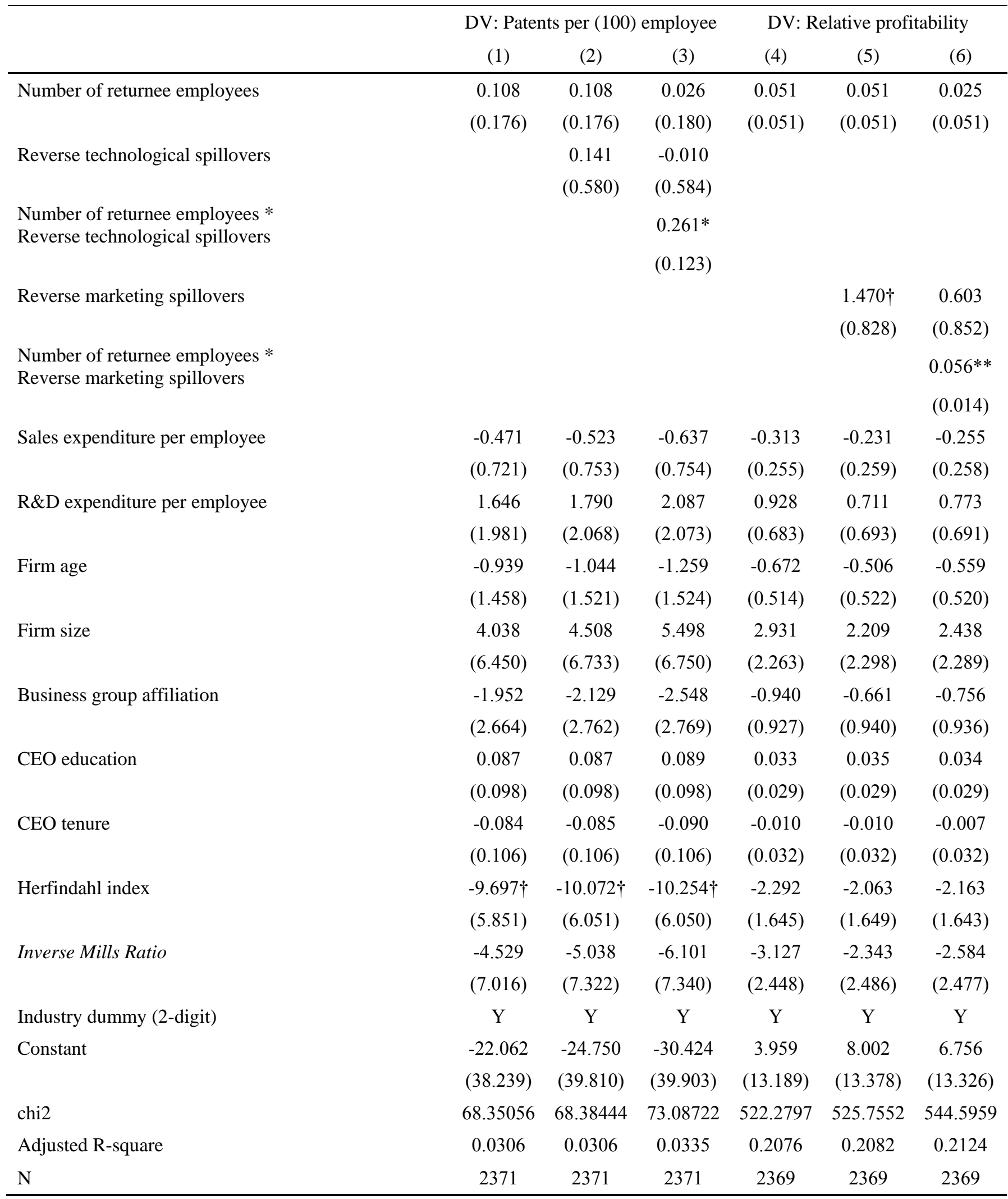

Note: $(1) \dagger, *$, and $* *$ represent statistical significance at $10 \%, 5 \%$ and $1 \%$, respectively.

(2) The number in the brackets shows standard errors. 